\title{
Detecting Changes in Hydro-Climatic Variables during the Last Four Decades (1975-2014) on Downstream Kaduna River Catchment, Nigeria
}

\author{
G. Chinwendu Okafor ${ }^{*}$, O. D. Jimoh ${ }^{2}$, K. Isaac Larbi ${ }^{3}$ \\ ${ }^{1}$ Faculty of Civil Engineering, Kwameh Nkrumah University of Science and Technology, Kumasi, Ghana \\ ${ }^{2}$ College of Civil Engineering, Federal University of Science and Technology, Minna, Nigeria \\ ${ }^{3}$ Department of Hydrology, University of Abomey-Calavi, Cotonou, Benin \\ Email: *gloriacokafor@yahoo.com
}

How to cite this paper: Okafor, G.C., Jimoh, O.D. and Larbi, K.I. (2017) Detecting Changes in Hydro-Climatic Variables during the Last Four Decades (1975-2014) on Downstream Kaduna River Catchment, Nigeria. Atmospheric and Climate Sciences, 7, 161-175.

https://doi.org/10.4236/acs.2017.72012

Received: December 1, 2016

Accepted: March 19, 2017

Published: March 22, 2017

Copyright (c) 2017 by authors and Scientific Research Publishing Inc. This work is licensed under the Creative Commons Attribution International License (CC BY 4.0).

http://creativecommons.org/licenses/by/4.0/

cc) (i) Open Access

\begin{abstract}
This study aimed to detect trends in the long-term hydro-climatic series using non-parametric methods. The annual and seasonal linear trends of rainfall, temperature, runoff, water level and evaporation were analysed for stations in downstream Kaduna River Basin during 1975-2014. The non-parametric Mann-Kendall and Sen's estimator of slope procedures were adopted to identify if there exists an increasing or decreasing trend with their statistical significance at $95 \%$ level of confidence. The datasets were checked to account for auto-correlation prior to determining trends using Mann-Kendall test. The existence of abrupt changes was detected by means of Cumulative Sum Charts and Bootstrapping analysis. The results of study indicated increasing trends for seasonal and annual temperature and runoff series. Water level and evaporation revealed statistically decreasing trends both on annual and seasonal periods. However, for the period 1975 to 2014 no significant distinctive trend was observed for rainfall at the investigated stations. Change-points in time series were identified in all the investigated hydro-climatic records for the sub-basin. Generally, the detection of the trend for hydro-climatic variables by Mann-Kendall test conforms to Sen's test results. It is concluded that the basin is sensitive to climate variability and water stress impacts which will affect food security. So, it would be necessary to make adjustments in the adaptive water-use strategies being adopted at present in the catchment.
\end{abstract}

\section{Keywords}

Hydro-Climatic Variables, Kaduna River, Trend Analysis, Mann-Kendall Test, Theil-Sen's Slope Estimator 


\section{Introduction}

Global and regional changing climate and variabilities including their societal impacts over the past three decades have received a considerable concern from the scientific community. Some of the major impacts of climate change consist of changes in precipitation patterns, average and maximum temperatures, mean sea level, and altered frequencies and intensities of extreme weather. The fifth Intergovernmental Panel on Climate Change assessment stated Africa surface temperature already increased by $0.5^{\circ} \mathrm{C}-2^{\circ} \mathrm{C}$ over the past hundred years and an observed drop in average annual rainfall of approximate $25-50 \mathrm{~mm}$ each decade from 1951-2010 in some parts of West Africa while globally averaged combined land and ocean surface temperature show a warming of $0.85^{\circ} \mathrm{C}$ over the period 1880 to 2012 [1] [2]. In general, [3] [4] projected an increase in temperature between $3^{\circ} \mathrm{C}$ and $6^{\circ} \mathrm{C}$ at the end of the 21 st century as compared with the previous century. Further, $40 \%$ reduction of rainfall is projected for arid and semi-arid locations but, a slight increase in the tropics [2] [3].

In recent years, investigations on present and plausible future climate change patterns and impacts on water resources have become of great interest in different parts of the world because of their serious effects imparted on both human society and the natural environment. The world is projected to become increasingly water stressed under climate impacts and population growth [5] [6]. Interconnections between the climate system, water cycle, biophysical and socioeconomic systems are complex, so a change in any one invariably induces change in others. Notably, climate change is likely to accelerate the global hydrological cycles, and a greater increase is expected in extreme rainfall as compared to the mean [7] and higher temperatures it will increase evaporation. In fact, temperature, evapo-transpiration and rainfall changes mainly influence the distribution of river flows and groundwater recharge [8]. With respect to climate variability and change impact on water resources, recent detected decreasing trend in water resources will continue in the future due to warming and rainfall declines [9] and a decrease in runoff is expected for 2050 [10].

Temperature and rainfall are fundamental components of climate, and so, the analysis of changes in these climatic variables characterizes key task in detecting climatic changes. Substantial efforts have been devoted to the study of hydroclimate variables [11]-[16]. Moreover, understanding the variations of rainfall, temperature and runoff at the basin scale provides opportunity to study the changing climate impact on water resources and hydrological cycle [17] [18] [19] [20]. For example, identified significant positive uptrend in rainfall is reflected in surface runoff yield [21] and rainfall effectiveness is considerably reduced due to high rate of water loss by evapotranspiration especially in the drier tropics. In addition, high agreement has been observed between historical observations and indigenous perceptions on impacts of climate change in the communities [11].

Despite the recent progress, hydro-climatic investigations and hydrological studies in Nigeria are still relatively scanty and mostly in small river basins especially in 
northern Nigerian basins. In fact, most of the previous studies have focused on temporal and spatial trends [22], magnitude and frequency of rainfall and runoff occurrence for various return periods [23], response patterns of hydrological parameters [24], effects of climate change [14] [25], and flood analysis [27].

Understanding the spatial and temporal variability of rainfall and runoff is challenging and requires high quality observed datasets. The trends of observational and historical hydro-climatic data reflect variations in climate and are generally used to determine appropriate adaptation strategies and also in the planning and designing of water resources projects. Over the country, extensive studies of hydrological phenomena have been limited because the spatial distribution of gauge stations is not adequate enough to allow the description of local and large-scale hydrological phenomena. The problems of scarce hydro-climatic data and limited hydrological studies are also applicable in the Kaduna basin. Reference [24] studied 30 hydro-climatic variables generated from 30 sub basins of the Upper Kaduna Catchment covering 10 years (1979-1989). The research revealed that behaviour of hydrological variables in the tropics and indeed, in Nigeria is largely misunderstood as different basin variables explained response patterns of individual flow types.

A variety of statistical analyses such as reduction method, standardized anomaly indices (SAIs), multivariate analysis, simple to multiple regression statistics have been applied to determine trends and inconsistencies of hydro-meteorological variables with the purpose of studying climate change impacts on hydrology and water resources [26] [27] [28] [29]. The Mann-Kendall (MK) nonparametric test is widely used for detecting a trend in hydro-climatic time series [15] [26] [30] [31]. At 5\% significance level, [27] revealed increasing statistically significant trends in temperature and rainfall for 9 states in the North-eastern U.S for the time period (1900 to 2011) using the modified Mann-Kendall test. Similarly, [32] showed that the trend pattern of stream flow, rainfall, temperature and evaporation from 2002-2012 was particularly on the increase when compared to previous decades for River Kaduna. However, they did not look at abrupt changes or seasonal variations. In this study, the Mann-Kendall, Sen's estimator of slope and Cumulative Sum Charts and Bootstrapping analysis are employed to detect trends and abrupt changes in the hydro-climatic series.

Overall investigations of trends of hydro-climatic variables at sub-catchment level in Nigeria and their implications on watersheds in previous studies were largely unexplored, though it's very pertinent for sustainable water resources usage. Similarly, inadequate availability of reliable hydro-climatic data limits such studies in the watershed. Uncertainties in the climate system and the complexities of hydrological processes add new challenges in the management of water resources. Thus, a study on hydro-climatic variables should be examined in support of efforts to adapt to changing climate in Nigeria and provide a base for further climate change research for the study location. Therefore, the aim of present study is to identify existing hydro-climatic trends and variation in Kaduna River at the sub-catchment level with focus on its impact on water availability. The study attempts to address the following: a) Are there evidence of trends or long term 
changes in temperature, runoff, rainfall, water level and evaporation in the downstream Kaduna river basin? b) What are the patterns of variation? Are they increasing or decreasing or are they characterized by abrupt changes?

\section{Methodology}

\subsection{Study Area}

The Kaduna River is one of the tributary to Niger River in Nigeria originating from the Jos Plateau flowing through Kaduna town into Niger State, where it meets the Niger River at Nupeco. The downstream basin of the river is situated on the eastern part of Niger state (also known as Power State) comprises of Shiroro reservoir watershed and stretches to Lavun in Niger state (Figure 1). Kaduna river is situated between latitudes $09^{\circ} 06^{\prime} 32.64^{\prime \prime} \mathrm{N}$ and $10^{\circ} 30^{\prime} 12.64^{\prime \prime} \mathrm{N}$, and longitudes $05^{\circ} 30^{\prime} 39.34^{\prime \prime} \mathrm{E}$ and $07^{\circ} 04^{\prime} 44.34^{\prime \prime} \mathrm{E}$. The basin general climate has typical dry and wet seasons which are strongly influenced by highly variable topographic structure and low relief. The catchment receives on average annual rainfall is about $1204.91 \mathrm{~mm} /$ year, which gradually increases from north to south and temperature of $27.46^{\circ} \mathrm{C}$. On average there are 110 days/year with more than 0.1 $\mathrm{mm}$ of rainfall. The Shiroro dam reservoir $\left(320 \mathrm{~km}^{2}\right)$, was built primarily for purpose of supplying needed energy to power the country's growing economy

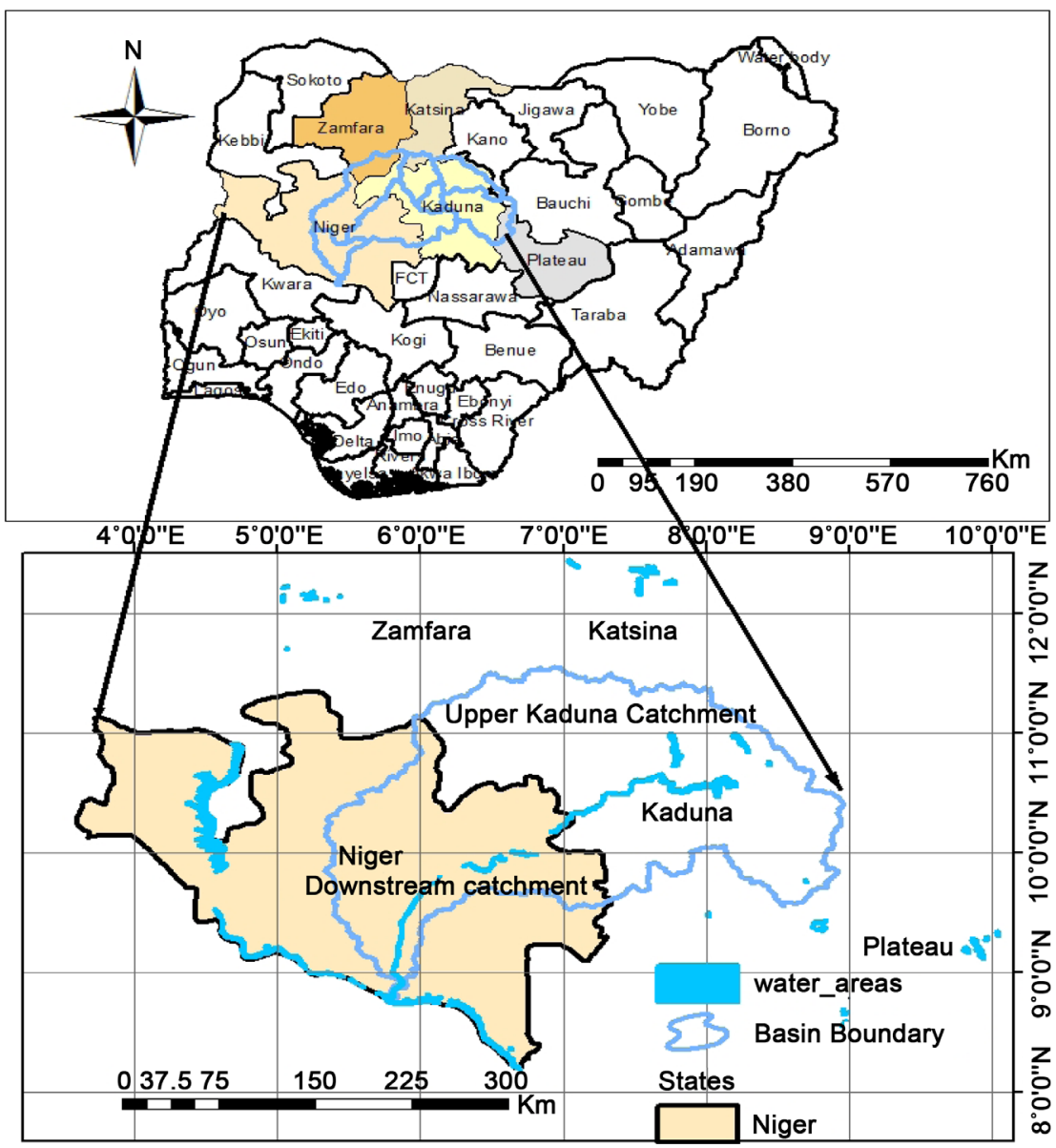

Figure 1. Location of downstream Kaduna river basin in Niger state. 
about 500 MW commissioned in 1990. Rain-fed and irrigated agriculture is the mainstay and the primary livelihood of the locals living within the watershed.

\subsection{Materials and Methods}

Series of daily maximum and minimum Temperatures, and Rainfall data obtained from Nigerian Meteorological Agency NIMET Abuja were used for this study. The stations used have continuous observations span the period 19752014. Similarly, daily runoff, water level and evaporation records of Kaduna river were obtained from Shiroro Hydro-Electric Power Station for a 25-year period (the maximum length of records that was made available) from 1990 to 2014.The daily values of temperature (minimum, average and maximum), rainfall and runoff were averaged over each month to assess trends in seasonal and annual scales. The seasons are thus defined as; rainy months: April to October \& dry season: months of November to March. Visual inspection has been used to detect outliers and ensure internal consistency. After data completion, the methods to determine serial correlation in the data series were observed.

This research based on statistical trend analysis to identify variations (gradual trends) and abrupt shifts in the data series of five hydro-climatic variables. Although, the linear trend tests results may sometimes suggest absence of significant trends, it is very valuable for determining potential explanations on the changing hydrological response of the river system.

\subsubsection{Normalization and Serial Correlation}

To test the presence of outliers in the time series data, the annual and seasonal time series of temperature, rainfall and runoff were tested to be normally distributed by using the Anderson-Darling test for normality at $\alpha=0.05$ significance level. In time series analysis using Mann Kendall rank method, it is essential to consider serial correlation [33] to check for randomness and periodicity in the series [34]. Serial correlation (also referred to as autocorrelation) increases variance of trend estimates and the odds of detecting significant trends even when absent and otherwise. A positive serial correlation can overestimate the likelihood of a trend and a negative correlation may result in underestimation. Serial correlation in the data series and description of the different methodologies used to correct climate data have been investigated and reported [35] [36] [37] [38]. The autocorrelation in the residuals of the annual temperature and rainfall series was checked using the ACF (autocorrelation) and PACF (partial autocorrelation) function at $\alpha=0.05$ significance level.

\subsubsection{The Mann-Kendall Trend Test}

To study the trend in the variables time series, the present study employed two non-parametric methods (Mann-Kendall rank correlation and Sen's slope estimator) in MAKESENS trend model to detect monotonic changes over time in climatic and hydrological data of the study area. The MAKESENS-a computer model introduced by [39] was developed using Microsoft Excel 97 and macros coded with the Microsoft Visual Basic. 
The non-parametric rank test was considered appropriate because no underlying frequency distribution of data could be assumed, and has been widely adopted to detect changes in hydro-climatic data time series [30] [31] [40]. In comparison to other non-parametric procedures, such as Spearman's rho test, the power of the Mann Kendal test is robust and similar to the extent of giving indistinguishable results in practice [36]. The Mann-Kendall statistic (S) [41] [42], theoretical calculation is shown in Equation (1).

$$
S_{m k}=\sum_{i=1}^{n} \sum_{j=i+1}^{n} \operatorname{sgn}\left(X_{j}-X_{i}\right)
$$

$X_{j}$ and $X_{i}$ are the annual data values in years $j$ and $i$, such that $(j>i)$ and where the sgn function is given as;

$$
\operatorname{sgn}\left(X_{j}-X_{i}\right)=\left\{\begin{array}{c}
1 \text { if }\left(X_{j}-X_{i}\right)>0 \\
0 \text { if }\left(X_{j}-X_{i}\right)=0 \\
-1 \text { if }\left(X_{j}-X_{i}\right)<0
\end{array}\right.
$$

Under the null hypothesis of no trend and independence of the series terms, the variance of the Mann-Kendall statistic is calculated as:

$$
\operatorname{Var}\left(S_{m k}\right)=\frac{N(N-1)(2 N+5)-\sum_{i=1}^{M} U_{i}(i)(i-1)(2 i+5)}{18}
$$

in which $M$ is the number of tied groups and $U_{i}$ denotes size of the $M^{\text {th }}$ group. The summation term in the numerator is used only if the data series contains tied values. For sample size $\mathrm{n} \geq 10$, the statistic $S$ assumes normal distribution, the standard normal test statistic $Z_{S}$ is computed using

$$
Z_{S}=\left\{\begin{array}{c}
\frac{S-1}{\sqrt{V A R(S)}}, \text { for } s>0 \\
0, \text { for } s=0 \\
\frac{S+1}{\sqrt{V A R(S)}}, \text { for } s<0
\end{array}\right.
$$

The trend results in this study have been evaluated at 5\% significant level (the corresponding threshold value is \pm 1.96 ). This implies that the null hypothesis is rejected when $\left|Z_{S}\right| \geq Z_{\alpha / 2}$ in Equation (4) at $\alpha=0.05$ level of significance. The alternate hypothesis is that a trend exists in the data. A positive $Z_{S}$ value indicates an increasing trend, while a negative $Z_{S}$ value indicates a decreasing trend. The significance levels ( $p$-values) for each trend test can be obtained from the relationship given as:

$$
p=0.5-\varphi\left(\left|Z_{s}\right|\right)
$$

where $\varphi()$ denotes the cumulative distribution function (CDF) of a standard normal variate. At a significance level of $5 \%$, if $p \leq 0.05$ then the existing trend is considered to be statistically significant.

\subsubsection{Thiel-Sen's Slope Analysis}

The trend magnitude is estimated using an unbiased median based slope esti- 
mator as initially proposed by [43] and modified by [30]. The slope estimation is given by:

$$
Q_{i}=\frac{\left(X_{j}-X_{k}\right)}{(j-k)} \text { for all } k<j \text { and } i=1, \ldots N
$$

where $Q_{i}=$ slope between data points $X_{j}$ and $X_{k}, X_{j}=$ data values at time $j, X_{k}=$ data values at time $k . \quad N=\frac{n(n-1)}{2}$ for single observation in each time period or $N<\frac{n(n-1)}{2}$, where $1<k<j<n$, and $\mathrm{n}$ is the total number of observations for each period. The $\mathrm{N}$ values of $Q_{i}$ are ranked from least to largest and median of these $\mathrm{N}$ values of $Q_{i}$ is the Sen's estimate of slope computed as:

$$
Q_{\text {med }}=\left\{\begin{array}{c}
Q[(n+1) / 2], \& \text { when } N \text { is odd } \\
Q\left(\frac{N}{2}\right)+Q\left[\frac{N+2}{2}\right], \text { when } N \text { is even }
\end{array}\right.
$$

The $Q_{\text {med }}$ sign reflects direction of trend in the data, while the value indicates steepness of the trend. By obtaining the confidence interval of $Q_{m e d}$ at specific probability, we determine whether the median slope is statistically different than zero. The confidence interval about the time slope [44] [45] can be computed as:

$$
C_{\alpha}=Z_{\alpha / 2} \sqrt{V(S)}
$$

where $\operatorname{Var}(S)$ is defined in Equation (3) and $Z_{\alpha / 2}$ is obtained from the standard normal distribution table.

\subsubsection{Cumulative Sum Charts and Bootstrapping}

A number of methods can be applied in determining shifts in the mean and variance of a time series. In this study, Cumulative Sum Charts (CUSUM) and Bootstrapping [46] were used to detect existence of abrupt change in climate series, when the point of change in the theoretical distribution of the statistic of interest is not well-known or if no parametric method is available. Application of the CUSUM and Bootstrapping methods in climatological studies can be found in studies such like [8] and [47].

The cumulative sums $S_{0}, S_{1} \ldots S_{n}$ of sample data $\left(X_{1}, X_{2}, \ldots, X_{n}\right)$, where $\mathrm{n}$ is the sample size, are calculated iteratively as follows: First, Compute mean of the sample data $(x)$; set $S_{0}=0$; and calculate $S_{i}$ recurrently as $S_{i}=S_{i-1}+\left(X_{i}-x\right) ; i=1$; 2 ; ...; n. This study was done based on 1000 bootstrap samples. Where the CUSUM chart follows a relatively straight line, it indicates a period when the average did not change, and while an abrupt change in the direction of the CUSUM signifies an abrupt shift in the average. The confidence level can be determined by performing bootstrap analysis. First, the magnitude of change $S_{\text {diff }}$ is calculated by $S_{\text {diff }}=S_{\max }-S_{\min }$, where $S_{\max }=\max _{\mathrm{i}}=1 ; \ldots ; n S_{i}$ and $S_{\min }=\min _{\mathrm{i}}=$ $1 ; \ldots ; n S_{p}$ and then, the bootstrap analysis can be performed as illustrated in the following steps:

1) Create bootstrap sample of $\mathrm{n}$ units, denoted as $X_{1}^{0}, X_{2}^{0}, \ldots, X_{n}^{0}$, by ran- 
domly reordering the original $\mathrm{n}$ values from your data. 2) Using the bootstrap sample, calculate the bootstrap CUSUM, denoted as $S_{1}^{0}, S_{2}^{0}, \ldots, S_{n}^{0}$. 3) Find the maximum, minimum and the difference of the bootstrap CUSUM, $S_{\max }^{0}$, $S^{0}$ min and $S^{0}$ diff, respectively. 4) Then determine the bootstrap difference $S_{\text {diff }}^{0}$ and check if it's less than the original difference Sdiff. 5) Repeat the above procedure (1)-(4) $\mathrm{n}$ times. 6) if $\mathrm{X}$ is the number of bootstraps for which $\mathrm{S}^{0}$ diff $<$ Sdiff, then, the confidence level (CL) at which the change point occurred is

$$
C L=100 * \frac{X}{n}(\%)
$$

Slope change ratio of cumulative quantity (SCRCQ).

To estimate the location of the change point, define $\mathrm{m}$ such that: $|\mathrm{Sm}|=$ $\max _{\mathrm{i}=1 ; \ldots ; \mathrm{n}}|\mathrm{Si}|$, which is the point furthest from 0 in the CUSUM chart. The point " $m$ " estimates the last point before the change point occurred.

\section{Analysis and Results}

The Mann-Kendall test and Sen's slope estimator were applied to the time-series of rainfall and temperature (1975-2014), runoff, water level and evaporation (1990-2014). The outcomes of the statistical test are summarized in Table 1 and Table 2. Evaluation of the change point results was mainly based on the results computed by CUSM Charts and Bootstrapping.

\subsection{Serial Correlation of the Hydro-Climatic Data}

Autocorrelation plots for the stations are presented in Figure 2. At lag 1, temperature, rainfall, runoff, evaporation and water level series are normalised and not auto-correlated.

Table 1. Statistical trend test results for the series of rainfall and temperature (19752014).

\begin{tabular}{|c|c|c|c|c|c|c|}
\hline & \multicolumn{3}{|c|}{ Minna } & \multicolumn{3}{|c|}{ Bida } \\
\hline \multicolumn{7}{|c|}{ Rainfall } \\
\hline Statistical test & Annual & Rainy & Dry & Annual & Rainy & Dry \\
\hline Mk statistics $\left(Z_{S}\right)$ & 0.41 & 0.69 & $-2.71^{* *}$ & 0.10 & 0.41 & -0.64 \\
\hline $\mathrm{p}$ & 0.68 & 0.49 & 0.01 & 0.92 & 0.68 & 0.52 \\
\hline $\mathrm{Q}_{\mathrm{med}}$ & 0.95 & 2.15 & -0.41 & 0.34 & 1.01 & - \\
\hline \multicolumn{7}{|c|}{ Average Temperature } \\
\hline $\mathrm{Z}_{\mathrm{S}}$ & $3.75^{* * *}$ & $2.04^{* *}$ & $4.72^{* * *}$ & 0.10 & $2.82^{* *}$ & -1.51 \\
\hline $\mathrm{p}$ & $0.00^{*}$ & $0.01^{*}$ & $<0.0001$ & 0.37 & $0.00^{*}$ & 0.16 \\
\hline $\mathrm{Q}_{\mathrm{med}}$ & 0.02 & 0.02 & 0.031 & 0.00 & 0.02 & -0.02 \\
\hline \multicolumn{7}{|c|}{ Maximum Temperature } \\
\hline $\mathrm{Z}_{\mathrm{S}}$ & $3.04^{\star *}$ & & & $4.14^{\star \star \star}$ & & \\
\hline $\mathrm{Q}_{\text {med }}$ & 0.02 & & & 0.03 & & \\
\hline \multicolumn{7}{|c|}{ Minimum Temperature } \\
\hline $\mathrm{Z}_{\mathrm{S}}$ & $2.71^{\star \star}$ & & & -1.95 & & \\
\hline $\mathrm{Q}_{\mathrm{med}}$ & 0.02 & & & -0.02 & & \\
\hline
\end{tabular}

$Z_{S}$ : MK test, $p$-value, $\mathrm{Q}_{\text {med }}:$ Sen's Slope estimator. ${ }^{*},{ }^{* *}{ }^{* * *}$ Significant trends $(\alpha=0.10,0.05 \& 0.01$ Sig. level). 


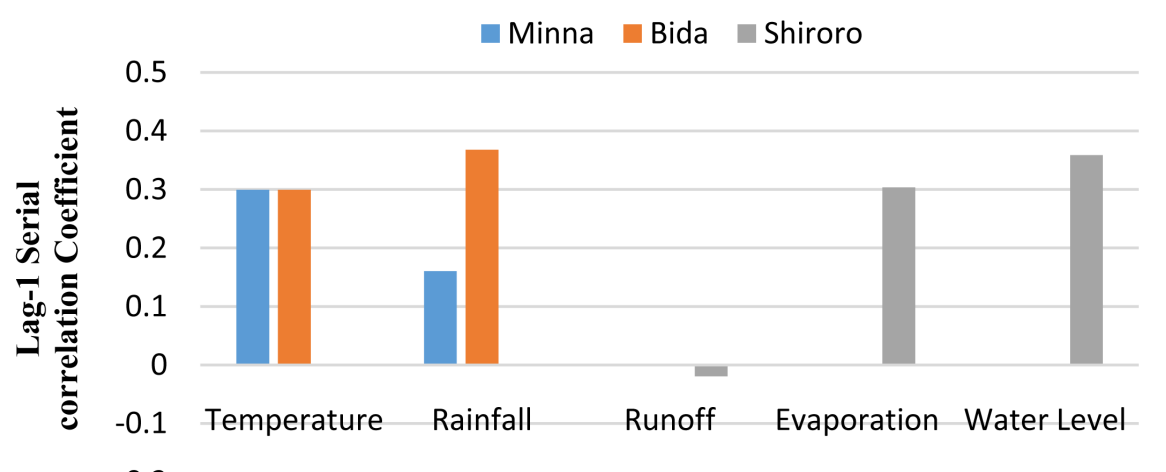

$-0.2$

\section{Hydroclimatic variables}

Figure 2. Serial correlation at lag-1.

Table 2. Annual runoff, water level and evaporation trend test statistic results at Shiroro gauging station (1990-2014).

\begin{tabular}{cccc}
\hline \multirow{2}{*}{ Statistical test } & \multicolumn{3}{c}{ Average Runoff } \\
\cline { 2 - 4 } & Annual & Rainy & Dry \\
\hline Mk statistics $\left(\mathrm{Z}_{\mathrm{S}}\right)$ & $2.51^{*}$ & 1.66 & $2.08^{*}$ \\
p-value & $0.02^{\star}$ & 0.08 & 0.07 \\
$\left(\mathrm{Q}_{\mathrm{med}}\right)$ & 2.14 & 2.06 & 1.68 \\
Kendell tau $(\tau)$ & 0.33 & 0.25 & 0.26 \\
& Average Water level & \\
$\left(\mathrm{Z}_{\mathrm{S}}\right)$ & $-3.90^{* * *}$ & $-4.09^{* * *}$ & $-2.87^{* *}$ \\
$\left(\mathrm{Q}_{\mathrm{med}}\right)$ & -6.45 & -7.17 & -5.49 \\
& Average Evaporation & & \\
$\left(\mathrm{Z}_{\mathrm{S}}\right)$ & $-4.09^{* * *}$ & $-2.64^{* *}$ & $-3.62^{* * *}$ \\
$\left(\mathrm{Q}_{\mathrm{med}}\right)$ & -1.30 & -0.33 & -0.83 \\
\hline
\end{tabular}

Source: Statistical test.

\subsection{Temporal Trends in Annual and Seasonal Rainfall and Temperature Analysed Using Mann-Kendall and Sen's Slope Statistics}

On running the MK statistic to test for the presence of trends, on rainfall and temperature data for 1974-2014 in the downstream Kaduna River basin, the following results as shown in Table 1 were obtained for annual, rainy and dry season periods at Minna, Bida and Shiroro stations. The test statistic $Z_{\mathrm{S}}$ was used as measure of significance in the trend. A positive $Z_{S}$ specifies an increasing trend, while decreasing trends are denoted by negative values. The null hypothesis $\left(\mathrm{H}_{0}\right)$ is rejected when $\left|Z_{S}\right|>1.96$ and the result is held to be statistically significant. If the $\mathrm{p}$-value is less than the significance level $\alpha=0.05, \mathrm{H}_{0}$ is rejected. Rejecting $\mathrm{H}_{0}$ shows that a trend exists in the time series, while accepting $\mathrm{H}_{0}$ indicates no trend was identified.

On the annual basis, it is seen from the results of the MK-statistics and $P$ value that no trend was detected in rainfall data in the catchment at $\alpha=0.05$ sig- 
nificance level. On the seasonal scale, no significant trend (positive nor negative) was spotted by the trend tests except for dry seasonal values at Minna station, which showed statistically significant decreasing trend with $Z_{\mathrm{S}}=-2.71$ and $p$ value $=0.01$ (less than 0.05 ). Temperature results in Table 1 indicated statistically increasing trends in both annual and seasonal temperature series for Minna station. Similar results were obtained from trend analysis for maximum and minimum temperatures. However, non-statistical declining trend was observed at Bida station in dry season and minimum temperature for period of study while annual and rainy season values show increasing trends. The results of trend analysis in rainfall on this research conforms with previous study by [14] and such a shift in the temperature distribution is generally consistent with previous trend studies that reported increasing mean temperature in the region [48]. However, [49] using observation and RCM data have predicted no trend in rainfall time series (from 2001-2065) and definite increasing temperature trend over the entire country in the period 1976-2065.

\subsection{Trend Direction $\left(Z_{s}\right)$, Magnitude $\left(Q_{m e d}\right)$ and Significance of Runoff, Water Level and Evaporation at Shiroro Gauging Station}

The values of the Mann-Kendall statistics $\left(\mathrm{Z}_{\mathrm{S}}\right)$, Sen's slope $\left(\mathrm{Q}_{\mathrm{med}}\right)$, and the $p$ value statistics are given in Table 2 to show time-based trends (annual and seasonal) runoff, water level and evaporation tested at 5\% significance level (twotailed). The statistical tests showed an increasing significant trend in annual runoff with the $Z$-value $=2.51>Z_{0.05 / 2}=1.96$, and by the $p$-value $0.02<0.05$. On seasonal basis, increasing trends that is statistically significant was identified for the dry season runoff series. Overall, the prevalent increasing trend in runoff was observed in the Kaduna River for the period 1990-2014 as seen by applying Mann-Kendall test. This can be attributed to the increases during the wet season as storm rainfall that runoff as flood and annual accumulation available during the dry season. However, water level and evaporation revealed statistically decreasing trends both on annual and seasonal periods. The differences in hydrological variables have been similarly observed by [32].

\subsection{Mann-Kendall Test in Comparison with the Sen's Slope Estimator for Detecting Trends in Hydro-Climatic Variables}

The Sen's estimator (Qmm/year) summarises change per unit time results of the trends identified. The Sen's slope estimator results obtained for annual and seasonal hydro-climatic series during the period 1975-2014 were shown in Table 1 and Table 2. Sen's estimator values ranges from $-0.41 \mathrm{~mm} /$ year at Minna station to $-77.39 \mathrm{~mm} /$ year at Shiroro. This latter result implies the existence of a nonmonotonic temporal pattern (both increasing and decreasing trends) in the time series. Variables having a negative trend $(-0.41,-0.02,-6.45$ and $-1.3 \mathrm{~mm} /$ year $)$ were identified as dry season rainfall for Minna station, minimum and dry season temperature for the Bida stations, water level and evaporation at Shiroro. In general, there is pronounced similarity between the Mann-Kendall and Sen's 
statistical results shown in this study at the 5\% significance level. [47] arrived at similar conclusion.

\subsection{Result of Change Points Identification in Time Series}

Change point analysis results performed for the hydro-climatic variables during the periods 1975-2014 and 1990-2014 were summarized in Table 3. As shown, change point can be seen for all hydro-climatic variables. Time series of temperature shows a change from negative to positive direction (increasing), while the other variables had the change from positive to negative direction (Figure 3 ).

Based on the results of the bootstrap analysis, the confidence level for the change point in temperature is $75 \%$. The confidence level for precipitation, water level, evaporation and runoff is $55 \%$.

\section{Discussion and Conclusion}

Mann-Kendall trend analysis and Sen's slope estimator are used in determining the changes in the hydro-climatic variables. In this study, the analysis of the MK test revealed that the series of temperature and runoff exhibited positive trends
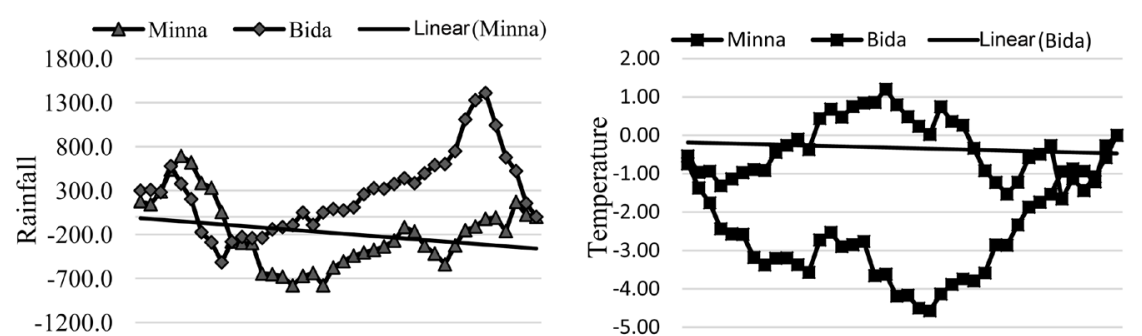

$-1200.0$
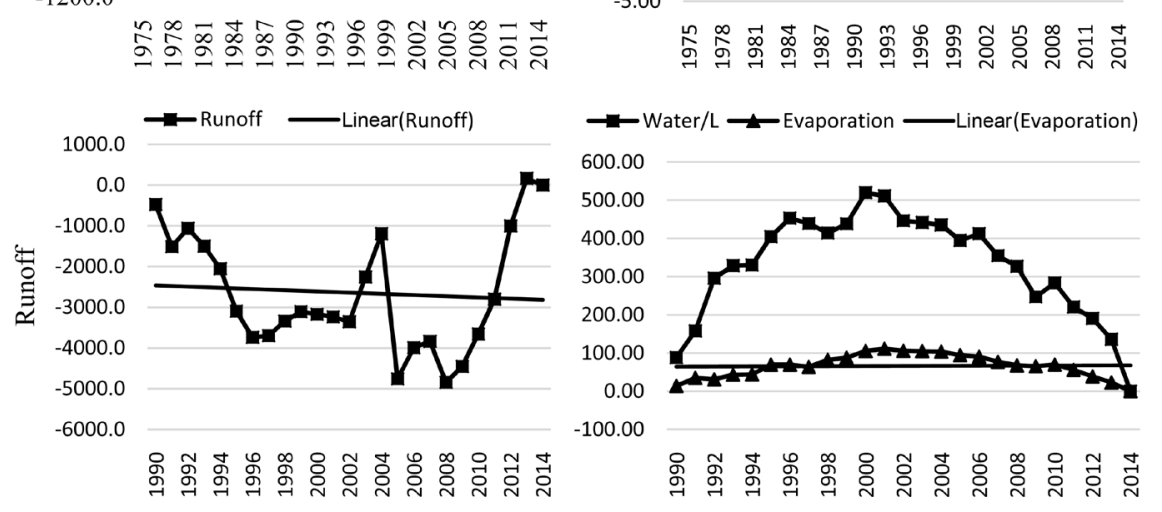

Figure 3. CUSUM charts for variables.

Table 3. Change point analysis in the hydro-climatic variables.

\begin{tabular}{ccccc}
\hline Station & Rainfall & $\mathrm{T}_{\text {ave }}$ & $\mathrm{T}_{\max }$ & $\mathrm{T}_{\min }$ \\
\hline Minna & $1990(+\rightarrow-)$ & $1997(-\rightarrow+)$ & $1994(-\rightarrow+)$ & $1997(-\rightarrow+)$ \\
Bida & $2009(+\rightarrow-)$ & $2009(+\rightarrow-)$ & $1993(+\rightarrow-)$ & $1993(+\rightarrow-)$ \\
& Runoff & Water/L & Evaporation & \\
\multirow{2}{*}{ Shiroro } & $2008(+\rightarrow-)$ & $2008(+\rightarrow-)$ & $2001(+\rightarrow-)$ & \\
\hline
\end{tabular}

$\rightarrow \rightarrow+$ change from negative to positive direction. $+\rightarrow-$ : change from positive to negative direction. 
which are statistically significant at $\alpha=0.05$. This implies that both variables have tended to increase. The warming in the area mainly resulted from significant increases in rainy season temperature. However, there is no significant distinctive trend observed for rainfall at the investigated climate stations except for decreasing dry season rainfall at Bida. In general, the changes in the indices of rainfall, temperature, runoff, water level and evaporation showed the possibility of the occurrence of drier climate and flood events. These hydrological changes are resulting from collective effects of temperature and rainfall variations. As expected, significant increasing runoff trends, especially during the dry season may be attributed to storm rainfall and inflows from tributaries such as rivers Dinya, Sarkin Pawa, Erena and Muyi into Shiroro reservoir and release from the dam.

The results clearly revealed there is existence of climatic variability due to variations in the downstream Kaduna basin, which, may have impacted negatively on the water resources and livelihoods of inhabitants in the area. Hence, it is of immense importance to quantify the environmental, economic, and social impacts that may well emanate from variable hydro-climatic trends in the area. Study should further be conducted to indisputably attribute the observed trends to the changing climate as well as provide a better explanation of the trends experienced in numerous hydrological variables. The study recommends adequate water resources management and strategies as an adaptive measure to the changing climate in the basin.

\section{Acknowledgements}

This study was financed by the West African Science Service Centre on Climate Change and Adapted Land use (WASCAL). The authors would like to express their thanks to the Nigerian Meteorological Agency NIMET Minna and Shiroro Hydro-Electric Power Station for providing data and Dr Ibrahim Seratu Usman for her contributions.

\section{References}

[1] IPCC (2013) Climate Change 2013: The Physical Science Basis. Contribution of Working Group I to the Fifth Assessment Report of the Intergovernmental Panel on Climate Change. In: Stocker, T.F., Qin, D., Plattner, G.-K., Tignor, M., Allen, S.K., Boschung, J., Nauels, A., Xia, Y., Bex, V. and Midgley, P.M., Eds., Cambridge University Press, Cambridge, United Kingdom and New York, NY, USA, 1535 p. https://doi.org/10.1017/CBO9781107415324

[2] IPCC (2014) Climate Change 2014: Synthesis Report. Contribution of Working Groups I, II and III to the Fifth Assessment Report of the Intergovernmental Panel on Climate Change. In: Core Writing Team, Pachauri, R.K. and Meyer, L.A., Eds., IPCC, Geneva, Switzerland, 151 p. http://www.ipcc.org

[3] Boko, M., Niang, I., Nyong A., Vogel, C., Githeko, A., Medany, M., Osman-Elasha, B., Tabo, R. and Yanda, P. (2007) Climate Change 2007: Impacts, Adaptation and Vulnerability. Contribution of Working Group II to the Fourth Assessment Report of the Intergovernmental Panel on Climate Change. Parry, M.L., Canziani, O.F., Palutikof, J.P., van der Linden, P.J. and Hanson, C.E., Eds., Cambridge University 
Press, Cambridge, 433-467.

[4] Carter, R. and Parker, A. (2009) Climate Change, Population Trends and Groundwater in Africa. Hydrological Sciences Journal, 54, 676-689.

https://doi.org/10.1623/hysj.54.4.676

[5] Wiltshire, A., Gornall, J., Booth, B., Dennis, E., Falloon, P., Kay, G. and Betts, R. (2013) The Importance of Population, Climate Change and $\mathrm{CO}_{2}$ Plant Physiological Forcing in Determining Future Global Water Stress. Global Environmental Change, 23, 1083-1097. https://doi.org/10.1016/j.gloenvcha.2013.06.005

[6] Arnell, N.W., Livermore, M.J.L., Kovats, S., Levy, P.E. and Nicholls, R. (2004) Climate and Socio-Economic Scenarios for Global-Scale Climate Change Impacts Assessments: Characterising the SRES Storylines. Global Environmental Change, 14, 3-20. https://doi.org/10.1016/j.gloenvcha.2003.10.004

[7] Ekpoh, I.J. and Nsa, E. (2011) Extreme Climatic Variability in North-Western Nigeria: An Analysis of Rainfall Trends and Patterns. Journal of Geography and Geology, 3, 51-62.

[8] Kundzewicz, Z.W. and Robson, A.J. (2004) Change Detection in Hydrological Records-A Review of the Methodology. Hydrological Sciences Journal, 49, 7-19. https://doi.org/10.1623/hysj.49.1.7.53993

[9] Alexandrov, V. and Genev, M. (2003) Climate Variability and Change Impact on Water Resources in Bulgaria. European Water, 1/2, 25-30.

[10] Oyerinde, G.T., Hountondji, F.C.C., Wisser, D., Diekkruger, B., Lawin, A.E., Odofin, A.J. and Afouda, A. (2015) Hydro-Climatic Changes in the Niger Basin and Consistency of Local Perceptions. Regional Environmental Change, 15, 1627-1637. https://doi.org/10.1007/s10113-014-0716-7

[11] Nenwiinia, S. and Kabandab, T. (2013) Trends and Variability Assessment of Rainfall in Vhembe South Africa. Journal of Human Ecology, 42, 171-176.

http://www.krepublishers.com/02-Journals/JHE/JHE-42-0-000-13-Web/JHE-42-2-0 00-13-Abst-PDF/JHE-42-2-171-13-2366-Kabanda-T-A/JHE-42-2-171-13-2366-Kab anda-T-A-Tx[9].pmd.pdf https://doi.org/10.5897/AJAR12.650

[12] Salarijazi, M., Ali-Mohammad, A.A., Adib, A. and Daneshkhah, A. (2012) Trend and Change-Point Detection for the Annual Stream-Flow Series of the Karun River at the Ahvaz Hydrometric Station. African Journal of Agricultural Research, 7, 4540-4552.

[13] Obasi, R.A. and Ikubuwaje, C.O. (2012) Analytical Study of Rainfall and Temperature Trend in Catchment States and Stations of the Benin-Owena River. Journal of Environment and Earth Science, 2, 9-21.

[14] Chen, H., Guo, S., Xu, C. and Singh, V.P. (2007) Historical Temporal Trends of Hydro-Climatic Variables and Runoff Response to Climate Variability and Their Relevance in Water Resource Management in the Hanjiang Basin. Journal of $\mathrm{Hy}_{\text {- }}$ drology, 344, 171-184. https://doi.org/10.1016/j.jhydrol.2007.06.034

[15] Abdul Aziz, O.I. and Burn, D.H. (2006) Trends and Variability in the Hydrological Regime of the Mackenzie River Basin. Journal of Hydrology, 319, 282-294. https://doi.org/10.1016/j.jhydrol.2005.06.039

[16] Adeaga, O. (2006) Multi-decadal Variability of Rainfall and Water Resources in Nigeria. Proceedings of the International Association of Hydrological Sciences, 2, 294-299. https://doi.org/10.5194/piahs-370-97-2015

[17] Odunuga, S., Adegun, O., Raji, S.A. and Udofia, S. (2015) Changes in Flood Risk in Lower Niger-Benue Catchments. Proceedings of the International Association of Hydrological Sciences, 370, 97-102. https://doi.org/10.5194/piahs-370-97-2015 
[18] Abdulfatai, I.A., Okunlola, I.A., Akande, W.G., Momoh, L.O. and Ibrahim, K.O. (2014) Review of Gully Erosion in Nigeria: Causes, Impacts and Possible Solutions. Journal of Geosciences and Geomatics, 2, 125-129.

[19] Gebrekristos, S.T. (2015) Understanding Catchment Processes and Hydrological Modelling in the Abay/Upper Blue Nile Basin. Ethiopia.

[20] Suleiman, Y.M. and Ifabiyi, I. (2014) The Role of Rainfall Variability in Reservoir Storage Management at Shiroro. International Journal of Science and Technology, 7, 55-63.

[21] Hamed, K.H. and Rao, A.R. (1998) A Modified Mann-Kendall Trend Test for Autocorrelated Data. Journal of Hydrology, 204, 182-196. https://doi.org/10.1016/S0022-1694(97)00125-X

[22] Akinsanola, A.A. and Ogunjobi, K.O. (2016) Recent Homogeneity Analysis and Long-Term Spatio-Temporal Rainfall Trends in Nigeria Recent Homogeneity Analysis and Long-Term Spatio-Temporal Rainfall Trends in Nigeria. Journal of Theoretical and Applied Climatology, 1-15.

[23] Dike, B.U. and Nwachukwu, B.A. (2003) Analysis of Nigerian Hydrometeorological Data. Nigerian Journal of Technology, 22, 29-38.

[24] Ifabiyi, I.P. (2013) A Rank-Reduced Analysis of Runoff Components and Their Response Patterns to Basin Parameters in the Northern Basement Complex, Nigeria. Civil and Environmental Research, 3, 11-19.

[25] Ayinde, O.E., Ojehomon, V.E.T., Daramola, F.S. and Falaki, A.A. (2013) Evaluation of the Effects of Climate Change on Rice Production in Niger State, Nigeria. Ethiopian Journal of Environmental Studies and Management, 6, 763-773. https://doi.org/10.4314/ejesm.v6i6.7S

[26] Salami, A.W., Sule, B.F. and Okeola, O.G. (2011) Assessment of Climate Variability on Kainji Hydropower Reservoir. Annual Conference of the National Association of Hydrological Sciences, Abuja, 18-21 October 2011.

[27] Haruna, G., Abubakar, I. and Tsoho, U. (2013) Fitting Probability Distribution Functions to Runoff Variability of \nKaduna River. International Journal of Modern Engineering Research, 3, 2848-2852. http://www.ijmer.com/papers/Vol3_Issue5/BM3528482852.pdf

[28] Ifeka, A. and Akinbobola, A. (2015) Trend Analysis of Precipitation in Some Selected Stations in Anambra State. Atmospheric and Climate Sciences, 5, 1-12. https://doi.org/10.4236/acs.2015.51001

[29] Nnaji, C.C., Mama, C.N. and Ukpabi, O. (2014) Hierarchical Analysis of Rainfall Variability across Nigeria. Theoretical and Applied Climatology, 123, 171-184. https://doi.org/10.1007/s00704-014-1348-Z

[30] Hirsch, R.M., Slack, J.R. and Smith, R.A. (1982) Techniques of Trend Analysis for Monthly Water Quality Data. Water Resources Research, 18, 107-121. https://doi.org/10.1029/WR018i001p00107

[31] Yue, S. and Wang, C. (2004) The Mann-Kendall Test Modified by Effective Sample Size to Detect Trend in Serially Correlated Hydrological Series. Water Resources Management, 18, 201-218. https://doi.org/10.1023/B:WARM.0000043140.61082.60

[32] Kuti, I.A., Animashaun, M.I., Olawale, B. and Abdullahi, S. (2015) Trend Analysis of Hydro-Meteorological Data for River Kaduna at Shiroro Dam Site, Niger State Nigeria. Journal of Scientific Research and Reports, 8, 1-12.

[33] Von Storch, V.H. (1995) Misuses of Statistical Analysis in Climate Research. In: Storch, H.V. and Navarra, A., Eds., Analysis of Climate Variability: Applications of Statistical Techniques, Springer, Berlin, 11-26. 
https://doi.org/10.1007/978-3-662-03167-4_2

[34] Modarres, R. and Silva, V.P.R. (2007) Rainfall Trends in Arid and Semi-Arid Regions of Iran. Journal of Arid Environments, 70, 344-355.

https://doi.org/10.1016/j.jaridenv.2006.12.024

[35] Yue, S. and Wang, C.Y. (2002) The Applicability of Pre-Whitening to Eliminate the Influence of Serial Correlation on the Mann-Kendall Test. Water Resources Research, 38, 4-1-4-7.

[36] Yue, S., Pilon, P., Phinney, B. and Cavadias, G. (2002) The Influence of Autocorrelation on the Ability To Detect Trend in Hydrological Series. Hydrological Processes, 16, 1807-1829. https://doi.org/10.1002/hyp.1095

[37] Bayazit, M. and Önöz, B. (2008) To Prewhiten Or Not to Prewhiten in Trend Analysis? Hydrological Sciences Journal, 52, 611-624. https://doi.org/10.1623/hysj.52.4.611

[38] Blain, G.C. (2013) Seasonal Variability of Maximum Daily Rainfall in Campinas, State of São Paulo, Brazil: Trends, Periodicities, and Associated Probabilities. Acta Scientiarum, 35, 557-564.

[39] Salmi, T., Maatta, A., Anttila, P., Ruoho-Airola, T. and Amnell, T. (2002) Detecting Trends of Annual Values of Atmospheric Pollutants by the Mann-Kendall Test and Sen's Slope Estimates-The Excel Template Application MAKESENS. Finnish Meteorological Institute, Publications on Air Quality No. 31, Helsinki.

[40] Hu, Y. (2014) Water Tower of the Yellow River in a Changing Climate: Toward an Integrated Assessment. UNESCO-IHE Institute for Water Education, Delft. http://repository.tudelft.nl/assets/uuid:f53620b8-3ce5-4f4b-9b48-a27d8c0496d5/201 4_UNESCO-IHE_PHD_Thesis_YURONG_HU.pdf

[41] Mann, H.B. (1945) Nonparametric Tests against Trend. Econometrica, 13, 245-259. https://doi.org/10.2307/1907187

[42] Kendall, M.G. (1975) Rank Correlation Methods. Griffin, London.

[43] Sen, P.K. (1968) Estimates of the Regression Coefficient Based on Kendall's Tau. Journal of American Statistical Association, 63, 1379-1389. https://doi.org/10.1080/01621459.1968.10480934

[44] Hollander, M. and Wolfe, D.A. (1973) Nonparametric Statistical Methods. John Wiley and Sons, New York.

[45] Gilbert, R.O. (1987) Statistical Methods for Environmental Pollution Monitoring. John Wiley and Sons, New York.

[46] Efron, B. and Tibshirani, R.J. (1993) An Introduction to the Bootstrap. Chapman and Hall, London. https://doi.org/10.1007/978-1-4899-4541-9

[47] Gocic, M. and Trajkovic, S. (2013) Analysis of Changes in Meteorological Variables Using Mann-Kendall and Sen's Slope Estimator Statistical Tests in Serbia. Global and Planetary Change, 100, 172-182. https://doi.org/10.1016/j.gloplacha.2012.10.014

[48] Adakayi, P.E. (2012) An Assessment of the Rainfall and Temperature Variations in parts of Northern Nigeria. PhD Thesis, Department of Geography and Planning, University of Jos, Jos.

[49] Raffaello, C., Valentini, R. and Santini, M. (2013) Toward Climate-Resilient Development in Nigeria. Directions in Development. World Bank, Washington DC. 
Submit or recommend next manuscript to SCIRP and we will provide best service for you:

Accepting pre-submission inquiries through Email, Facebook, LinkedIn, Twitter, etc. A wide selection of journals (inclusive of 9 subjects, more than 200 journals)

Providing 24-hour high-quality service

User-friendly online submission system

Fair and swift peer-review system

Efficient typesetting and proofreading procedure

Display of the result of downloads and visits, as well as the number of cited articles Maximum dissemination of your research work

Submit your manuscript at: http://papersubmission.scirp.org/

Or contact acs@scirp.org 